\title{
More Impaired Dynamic Ventilatory Muscle Oxygenation in Congestive Heart Failure than in Chronic Obstructive Pulmonary Disease
}

\author{
Ming-Lung Chuang ${ }^{1,2, *}$, I-Feng Lin ${ }^{3}$ and Meng-Jer Hsieh ${ }^{4,5} \mathbb{D}$ \\ 1 Division of Pulmonary Medicine and Department of Internal Medicine, Chung Shan Medical University \\ Hospital, Taichung 40201, Taiwan \\ 2 School of Medicine, Chung Shan Medical University, Taichung 40201, Taiwan \\ 3 Institute and Department of Public Health, National Yang Ming University, Taipei 11221, Taiwan; \\ iflin@ym.edu.tw \\ 4 Department of Pulmonary and Critical Care Medicine, Chiayi Chang-Gung Memorial Hospital, \\ Chang-Gung Medical Foundation, Chiayi 61363, Taiwan; mengjer@yahoo.com \\ 5 Department of Respiratory Therapy, Chang Gung University, Taoyuan 33302, Taiwan \\ * Correspondence: yuan1007@ms36.hinet.net; Tel.: +886-4-2473-9595 (ext. 34718)
}

Received: 11 September 2019; Accepted: 2 October 2019; Published: 7 October 2019

check for updates

\begin{abstract}
Patients with chronic obstructive pulmonary disease (COPD) and congestive heart failure $(\mathrm{CHF})$ often have dyspnea. Despite differences in primary organ derangement and similarities in secondary skeletal muscle changes, both patient groups have prominent functional impairment. With similar daily exercise performance in patients with CHF and COPD, we hypothesized that patients with CHF would have worse ventilatory muscle oxygenation than patients with COPD. This study aimed to compare differences in tissue oxygenation and blood capacity between ventilatory muscles and leg muscles and between the two patient groups. Demographic data, lung function, and maximal cardiopulmonary exercise tests were performed in 134 subjects without acute illnesses. Muscle oxygenation and blood capacity were measured using frequency-domain near-infrared spectroscopy (fd-NIRS). We enrolled normal subjects and patients with COPD and CHF. The two patient groups were matched by oxygen-cost diagram scores, New York Heart Association functional classification scores, and modified Medical Research Council scores. COPD was defined as forced expired volume in one second and forced expired vital capacity ratio $\leq 0.7$. CHF was defined as stable heart failure with an ejection fraction $\leq 49 \%$. The healthy subjects were defined as those with no obvious history of chronic disease. Age, body mass index, cigarette consumption, lung function, and exercise capacity were different across the three groups. Muscle oxygenation and blood capacity were adjusted accordingly. Leg muscles had higher deoxygenation $(\mathrm{HHb})$ and oxygenation $\left(\mathrm{HbO}_{2}\right)$ and lower oxygen saturation $\left(\mathrm{S}_{\mathrm{m}} \mathrm{O}_{2}\right)$ than ventilatory muscles in all participants. The $\mathrm{S}_{\mathrm{m}} \mathrm{O}_{2}$ of leg muscles was lower than that of ventilatory muscles because $\mathrm{S}_{\mathrm{m}} \mathrm{O}_{2}$ was calculated as $\mathrm{HbO}_{2} /\left(\mathrm{HHb}+\mathrm{HbO}_{2}\right)$, and the $\mathrm{HHb}$ of leg muscles was relatively higher than the $\mathrm{HbO}_{2}$ of leg muscles. The healthy subjects had higher $\mathrm{S}_{\mathrm{m}} \mathrm{O}_{2}$, the patients with COPD had higher $\mathrm{HHb}$, and the patients with $\mathrm{CHF}$ had lower $\mathrm{HbO}_{2}$ in both muscle groups throughout the tests. The patients with CHF had lower $\mathrm{S}_{\mathrm{m}} \mathrm{O}_{2}$ of ventilatory muscles than the patients with COPD at peak exercise $(p<0.01)$. We conclud that fd-NIRS can be used to discriminate tissue oxygenation of different musculatures and disease entities. More studies on interventions on ventilatory muscle oxygenation in patients with CHF and COPD are warranted.
\end{abstract}

Keywords: near-infrared spectroscopy; frequency domain; heart failure; chronic obstructive pulmonary disease; maximal exercise; vastus lateralis muscle; serratus anterior muscle; cardiopulmonary exercise testing 


\section{Introduction}

Exercise intolerance and exertional dyspnea are often encountered in patients with chronic obstructive pulmonary disease (COPD) and cardiovascular diseases, and especially in those with congestive heart failure (CHF) [1]. The symptoms are primarily caused by heart and lung pathological changes that lead to physiological limitations, and secondarily by ventilatory and locomotor muscle weakness due to myopathy [1-4]. Causes of myopathy include hypoxia, oxidative stress, medication, nutritional depletion, systemic inflammation, disuse and atrophy (sarcopenia). However, functional impairment is more prominent than structural derangement. It has been hypothesized that functional impairment is further impaired by exercise due to failure of perfusion to meet the need of increased metabolism. Patients with CHF have primarily reduced central cardiovascular function, whereas patients with COPD have secondarily reduced central cardiovascular function caused by dynamic hyperinflation [5]. Moreover, the locomotor muscles are expected to be more impaired than the inspiratory muscles (diaphragm), as inspiratory muscles are more resistant to fatigue with a higher proportion of type I fibers, despite also being impaired in strength, whereas the quadriceps have a lower proportion of type I fibers [6-8]. Even though the mechanisms of myopathy, muscle morphology, muscle fiber type distribution and shifting, and muscle metabolism in the locomotor muscles are similar in patients with COPD and CHF [1,9], exercise-induced hypoxemia, if it occurs, is expected to aggravate hypoxic stress in patients with COPD, as the patterns of muscle cytochrome oxidase gene activation are altered in these patients [8]. In addition, hypoxemia may cause an increase in myostatin protein expression, which is related to muscle atrophy [10], and patients with COPD can experience vascular dysfunction with a higher extraction of muscle oxygen during exercise even in the early stage [11]. Therefore, it is not clear whether there are differences in the functions of locomotor and ventilatory muscles between patients with COPD and CHF who have similar daily exercise performance and dyspnea sensation.

Muscle function depends primarily on perfusion, muscle mass, fiber composition, and energy metabolism [1]. However, clinically, measurements of pressure, electromyography, and motor unit firing rates for ventilatory muscles [7], and strength and endurance for locomotor muscles [12], muscle oxygenation and perfusion measurements may be alternative methods to assess muscle function [13-17], and they have been reported to potentially be superior to the transdiaphragmatic tension time index [18]. Combining the indocyanine green dye (IGD) technique and near infrared spectroscopy (NIRS) has been reported to improve measurements of the peripheral muscle blood flow in healthy subjects and patients with COPD [19-22]. However, the IGD technique is sophisticated and its invasiveness related to the need to obtain arterial blood samples means that it is not widely used clinically. Subsequently, a relatively minimally invasive modified NIRS and IGD method to measure blood flow index was developed. The blood flow index has been shown to be highly correlated with muscle blood flow in ventilatory muscles and leg muscles in healthy subjects and patients with COPD [23-25]. However, the absolute blood flow cannot be determined using the blood flow index method.

With advances in NIRS technology, frequency-domain NIRS (fdNIRS) is capable of providing absolute values rather than relative changes in value [26]. This improvement allows for direct comparisons of oxygenation in different musculatures and different groups of subjects. Therefore, using fdNIRS, this study aimed to investigate differences in the balance of offering and utilizing oxygenation in leg and ventilatory musculature in non-obese healthy subjects and patients with COPD and CHF. This is the first study to compare the oxygenation of ventilatory and leg muscles between patients with COPD and CHF who have similar daily physical activity.

\section{Methods}

\subsection{Study Design}

In this observational study, we compared oxygenation and perfusion in two local musculatures during exercise as measured by near infrared spectroscopy (NIRS) across three groups of participants 
(healthy subjects, patients with COPD, and patients with CHF). The local Institutional Review Boards of Chung Shan Medical University Hospital (CS11144 and CMRPG32058) approved this study, which was conducted in compliance with the Declaration of Helsinki. Signed informed consent was obtained from each participant. The study was registered at Chung Shan Medical University Hospital (CSH-2012-C-23).

\subsection{Subjects}

Adult subjects were screened, enrolled, and allocated into COPD, CHF, and control groups from two university hospitals in Taiwan if they agreed to participate in the study. COPD was defined according to the GOLD guideline as follows [27]: a history of cigarette smoking for $\geq 10$ pack-years; forced expired volume in one second and forced expired vital capacity ratio $\left(\mathrm{FEV}_{1} / \mathrm{FVC}\right) \leq 0.7$, and no significant bronchodilation in a stable condition. Stable CHF was defined as stable heart failure with a mid-range or reduced ejection fraction (EFmrHF or EFrHF, i.e., $\mathrm{EF} \leq 49 \%$ ) with or without peripheral vascular disease as confirmed by the cardiologists of the institutes [28]. Healthy subjects were defined as those with no obvious history of chronic disease such as severe hypertension, uncontrolled mild hypertension [29], other cardiovascular diseases, diabetes mellitus, organ disease, autoimmune diseases, cancer, anemia, psychiatric diseases or aliments of the lower extremities affecting exercise, and acute illnesses.

\subsection{Measurements}

\subsubsection{Clinical Assessment Tests}

The subjects used the oxygen-cost diagram (OCD) [30] to assess daily activities. They were asked to indicate a point on an OCD, a 100-mm-long vertical line with everyday activities listed alongside the line, above which breathlessness limited them. The distance from zero was measured and scored. The New York Heart Association functional classification (NYHAfc) and modified Medical Research Council (mMRC) scales were also used to grade the functional status of the cardiopulmonary participants $[28,30]$. The mMRC scale includes 5 grades from 0 indicating "I only get breathless with strenuous exercise" to 4 "I am too breathless to leave the house".

\subsubsection{Pulmonary Function Testing}

$\mathrm{FEV}_{1}$, total lung capacity (TLC), and diffusing capacity for carbon monoxide $\left(\mathrm{D}_{\mathrm{L}} \mathrm{CO}\right)$ were measured using spirometry and body plethysmography in accordance with the currently recommended standards.

\subsubsection{Cardiopulmonary Exercise Testing (CPET)}

Each subject completed a ramp-pattern exercise test from resting to unloading, and the limit of their tolerance. Work rate was selected at a rate of 5-20 watts/minute depending on their fitness so that they could complete the loaded exercise within 8-12 min. Their fitness was evaluated using an OCD scale, and the ramp slope was selected on the basis of their fitness [31]. The time for loaded exercise was $8.4 \pm 1.7 \mathrm{~min}$ for all subjects. Oxygen uptake $\left(\dot{\mathrm{VO}}_{2}, \mathrm{~mL} / \mathrm{min}\right), \mathrm{CO}_{2}$ output $\left(\dot{\mathrm{VCO}}_{2}, \mathrm{~mL} / \mathrm{min}\right)$, minute ventilation $\left(\dot{\mathrm{V}}_{\mathrm{E}}\right)$, blood pressure, oxyhemoglobin saturation assessed by pulse oximetry $\left(\mathrm{S}_{\mathrm{P}} \mathrm{O}_{2}\right)$, blood pressure, and Borg dyspnea score were measured.

\subsubsection{Near Infrared Spectroscopy (NIRS)}

An OxiplexTS ${ }^{\mathrm{TM}}$ system (ISS, Champaign, IL, USA) was used to measure deoxygenated and oxygenated hemoglobin and intracellular myoglobin $\left(\mathrm{HHb}+\mathrm{HMb}\right.$ and $\left.\mathrm{HbO}_{2}+\mathrm{MbO}_{2}\right)[32,33]$. Even though $(\mathrm{Mb})$ is likely to contribute $60 \%-90 \%$ to the NIRS signals coming from skeletal muscles [34], for simplicity, we used $\mathrm{HHb}$ and $\mathrm{HbO}_{2}$ instead of $\mathrm{HHb}+\mathrm{HMb}$ and $\mathrm{HbO}_{2}+\mathrm{MbO}_{2}$. The distance between the transmitter and receiver optodes of the NIRS system was $4 \mathrm{~cm}$. NIRS is usually expressed by 
relative values instead of absolute values. However, the OxiplexTS ${ }^{\mathrm{TM}}$ system can provide absolute values of tissue saturation in real time [26,35], and it is therefore possible to explicitly compare the magnitudes of responses in tissue $\mathrm{HHb}, \mathrm{HbO}_{2}$, the sum of both (total blood capacity, TOT), and tissue saturation or the tissue oxygenation index (the fraction of oxygenation and sum of the two laser diode wavelengths, $\mathrm{S}_{\mathrm{m}} \mathrm{O}_{2}$, \%). As TOT cannot be used to represent blood flow [36], we defined the sum of $\mathrm{HHb}$ and $\mathrm{HbO}_{2}$ as the total blood capacity, which included arterial, capillary, and venous blood volumes. A calibration block was used before each test as recommended by the manufacturer. The leg probe of the OxiplexTS ${ }^{\mathrm{TM}}$ system was positioned over the vastus lateralis muscle $10-12 \mathrm{~cm}$ above the knee, parallel to the major axis of the thigh [37], and the thoracic probe was positioned approximately at the sixth intercostal space along the anterior axillary line [38] to monitor the anterior serratus and intercostal muscles [39]. We selected the anterior serratus muscle because fatigue of this muscle is accompanied with diaphragmatic fatigue during incremental exercise [40] and during the latter stages of maximal exercise (75\% of maximum $\mathrm{V}_{2}$ and more [41]), and becomes dominant in hyperventilation [42,43]. A piece of plastic wrap was used to prevent the lamp from becoming fogged by sweat during exercise. An elastic strap was used to secure the leg probe and adhesive tape was used to secure the chest probe. The sampling frequency of the fdNIRS device was set at $1 \mathrm{~Hz}$. For simplicity, NIRS data were averaged and presented for the last $15 \mathrm{~s}$ of rest, unloaded pedaling and peak loaded exercise. Of note, at peak exercise, the nadir was used for variables that decreased compared to the baseline and the peak was used for variables that increased. These data were used for information on the dynamic balance between $\mathrm{O} 2$ supply (possibly also including $\mathrm{O} 2$ store with myoglobin and cytochrome c) and $\mathrm{O} 2$ demand. We did not record the respiratory compensation point or the anaerobic threshold, as they are difficult to identify and measure at a single location during incremental exercise [44,45].

\subsection{Statistical Analysis}

Data were summarized as mean \pm standard deviation. The sample size was estimated to be at least 10 for each group when the population mean difference in $\mathrm{S}_{\mathrm{m}} \mathrm{O}_{2}$ was 5.5 with a standard deviation for the normal and CHF groups of 4 and with a significance level of 0.05 and a power of 0.8 [46]. For each outcome variable, the comparisons were planned a priori. In the univariate analysis, $p$ values were calculated by analysis of variance (ANOVA) with Tukey's correction for multiple comparisons to compare means across the three groups. The paired $t$ test was used to compare two related means between different time points. Fisher's exact method was used in a contingency table analysis for categorical variables. Muscle mass is related to age, body height and weight [47-49], and muscle hypoxia is affected by hypoxemia. Thus, general linear models were used in comparison of the three groups (normal, COPD, CHF), adjusting for potential confounders such as age, body mass index, and $\mathrm{SpO} 2$ at each time point, respectively. For comparisons within different time points for the same variable, we did not adjust for other confounders as the measurements were from the same subject and the comparisons were planned a priori [5]. During loaded exercise, the $\mathrm{HHb}$ level is workload-related $[35,42,50]$ and thus, the $\mathrm{Hb}$ variables were additionally corrected for peak workload. Pearson's correlation coefficients were used to quantify the pair-wise relationships between NIRS data and the demographic, lung function and peak exercise variables. All statistical analyses were performed using SAS statistical software (9.4, SAS Institute Inc., Cary, NC, USA). Statistical significance was set at $p<0.05$.

\section{Results}

\subsection{Population Characteristics}

A total of 175 subjects were screened and 134 subjects were retained for analysis after excluding 41 subjects (Figure 1 and Table 1). The subjects were allocated into three groups (Table 1). Differences in OCD, NYHAfc, and mMRC scores between the patients with COPD and CHF were insignificant 
(all $p=\mathrm{NS}$ ). The etiologies of CHF are shown in Table 1. Differences in demographic data, symptom scores, resting lung function, exercise physiology, $\mathrm{S}_{\mathrm{P}} \mathrm{O}_{2}$ and performance of peak exercise in the three groups are shown in Tables 1 and 2.

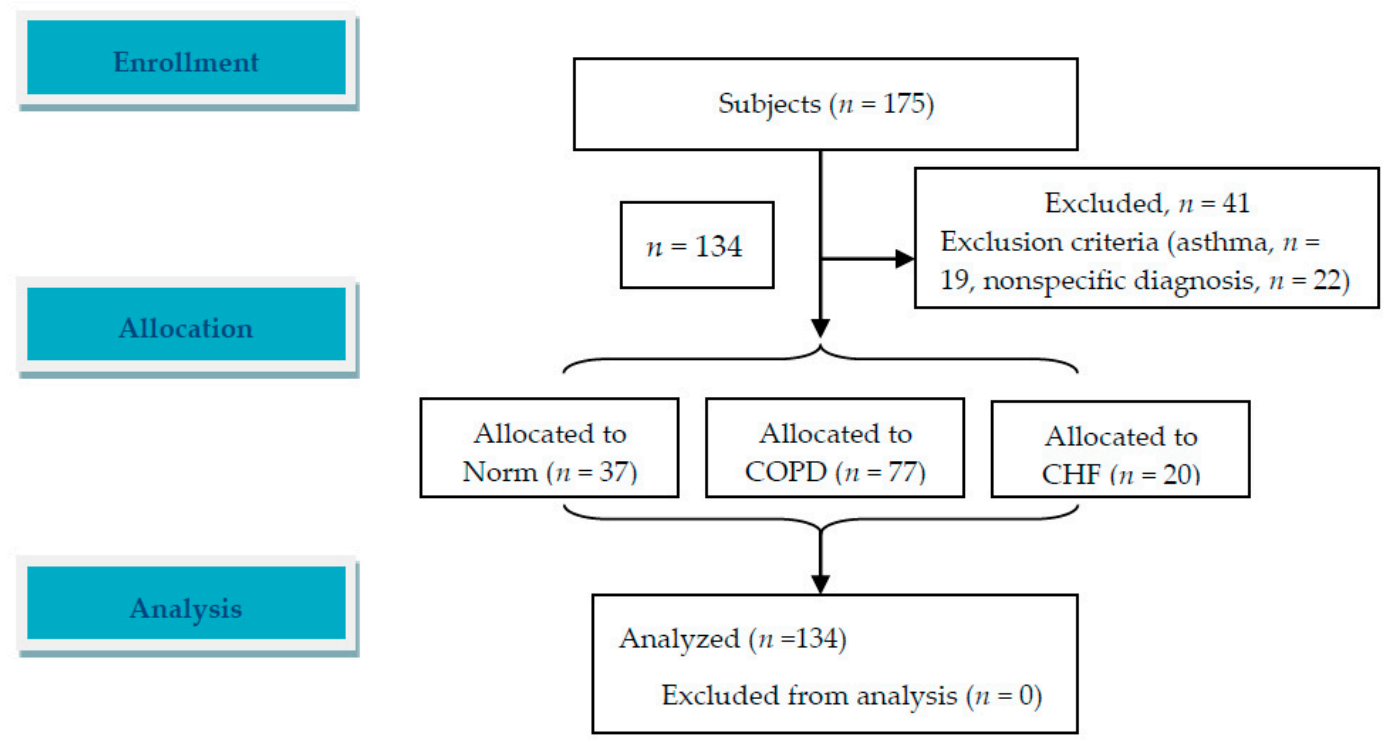

Figure 1. An image of flow diagram. A total of 175 subjects were screened and 134 patients were enrolled and analyzed. Follow-up was not applicable in this study.

Table 1. Demographic data, symptom scores, lung function and oxyhemoglobin saturation measured with pulse oximetry $\left(\mathrm{S}_{\mathrm{P}} \mathrm{O}_{2}\right)$ and oxygen uptake $\left(\mathrm{VO}_{2}\right)$ at rest.

\begin{tabular}{|c|c|c|c|c|c|c|c|}
\hline \multirow[t]{2}{*}{ Group } & \multicolumn{2}{|c|}{ Normal } & \multicolumn{2}{|c|}{ COPD } & \multicolumn{2}{|c|}{ CHF } & \multirow{2}{*}{$\frac{\text { ANOVA }}{p \text { Value }}$} \\
\hline & mean & SD & mean & SD & mean & SD & \\
\hline$n=134$ & 37 & & 77 & & 20 & & \\
\hline Age, years & 54.5 & 17.5 & 66.4 & 11.1 & 52.1 & 12.6 & $<0.0001$ \\
\hline Gender, M/F & $33 / 4$ & & $70 / 7$ & & $19 / 1$ & & 0.76 \\
\hline Body mass index, $\mathrm{kg} / \mathrm{cm}^{2}$ & 23.8 & 3.0 & 24.0 & 3.7 & 26.3 & 3.1 & $<0.05$ \\
\hline Oxygen-cost diagram, $\mathrm{cm}$ & 8.6 & 1.2 & 7.0 & 1.2 & 7.6 & 1 & $<0.0001$ \\
\hline NYHAfc, I, II, III (\%) & \multicolumn{2}{|c|}{-} & \multicolumn{2}{|c|}{$37.9,51.7,10.3$} & \multicolumn{2}{|c|}{$47.1,52.9,0$} & 0.58 \\
\hline mMRC, 0, 1, $2(\%)$ & \multicolumn{2}{|c|}{ - } & \multicolumn{2}{|c|}{$41.4,48.3,10.3$} & \multicolumn{2}{|c|}{$70.6,29.4,0$} & 0.14 \\
\hline Cigarette, pack $\cdot$ year & 4.8 & 17.5 & 58 & 33.2 & 31.8 & 26 & $<0.0001$ \\
\hline Co-morbidity, Yes/No & & & & & & & \\
\hline Hypertension, $n=$ & \multicolumn{2}{|c|}{$4 / 36 *$} & \multicolumn{2}{|c|}{$18 / 73 *$} & \multicolumn{2}{|c|}{$11 / 20$} & $<0.01$ \\
\hline Diabetes mellitus, $n=$ & \multirow{2}{*}{\multicolumn{2}{|c|}{$1 / 36^{*}$}} & \multirow{2}{*}{\multicolumn{2}{|c|}{$6 / 73^{*}$}} & \multicolumn{2}{|c|}{$1 / 20$} & 0.57 \\
\hline Lung function and others & & & & & & & \\
\hline FVC \%predicted, \% & 96 & 12 & 76 & 21 & 88 & 14 & $<0.0001$ \\
\hline $\mathrm{FEV}_{1} \%$ predicted, $\%$ & 97 & 10 & 59 & 22 & 88 & 14 & $<0.0001$ \\
\hline $\mathrm{FEV}_{1} / \mathrm{FVC}$ ratio, $\%$ & 81 & 7 & 59 & 15 & 82 & 5 & $<0.0001$ \\
\hline Ejection fraction ${ }^{\dagger}, \%$ & - & - & - & - & 44 & 7 & NA \\
\hline $\mathrm{VO}_{2}, \%$ predicted, $\%$ & 17 & 5 & 22 & 8 & 18 & 6 & $<0.01$ \\
\hline $\mathrm{S}_{\mathrm{P}} \mathrm{O}_{2}, \%$ & 97 & 1 & 96 & 3 & 97 & 1 & $<0.001$ \\
\hline
\end{tabular}

COPD: chronic obstructive pulmonary disease, CHF: congestive heart failure. FVC: forced expired capacity, NYHAfc: New York Heart Association functional classification, mMRC: modified Medical Research Council, $\mathrm{FEV}_{1}$ : forced expired volume in one second, ${ }^{*}$ missing one and four subjects, respectively. Participants with CHF included 1 subject with ventricular septal defect, 2 subjects waiting for heart transplantations, 3 subjects with decompensated cardiomyopathy, 13 subjects with coronary artery disease, and 1 subject with hypertensive cardiovascular disease.

${ }^{+}$Ejection fraction of the left ventricle using 2-dimensional echocardiography. 
Table 2. Cardiopulmonary exercise test at peak exercise.

\begin{tabular}{|c|c|c|c|c|c|c|c|}
\hline \multirow{2}{*}{ Group } & \multicolumn{2}{|c|}{ Normal } & \multicolumn{2}{|c|}{ COPD } & \multicolumn{2}{|c|}{ CHF } & \multirow{2}{*}{$\begin{array}{l}\text { ANOVA } \\
p \text { Value }\end{array}$} \\
\hline & mean & SD & mean & SD & mean & SD & \\
\hline Workload, WR, watt & 144 & 32 & 87 & 40 & 116 & 28 & 0.0002 \\
\hline WR, watt $\%$ predicted, $(\% p), \%$ & 107 & 26 & 78 & 27 & 81 & 27 & 0.42 \\
\hline Respiratory exchange ratio & 1.11 & 0.16 & 1.11 & 0.16 & 1.17 & 0.13 & 0.62 \\
\hline Oxygen uptake, $\dot{\mathrm{V}} \mathrm{O}_{2} \% p$, \% & 81 & 8 & 68 & 22 & 60 & 16 & 0.07 \\
\hline$\dot{\mathrm{VO}}_{2}, \mathrm{~mL} / \mathrm{min} / \mathrm{kg}$ & 30.4 & 4 & 17.6 & 6.3 & 18.4 & 2.6 & $<0.0001$ \\
\hline$\dot{\mathrm{VO}}_{2 \_ \text {anaerobic threshold } \% \text { max }} \%$ & 48 & 8 & 49 & 9 & 37 & 11 & 0.07 \\
\hline Cardiac frequency, $\mathrm{f}_{\mathrm{c}}, \% p, \%$ & 91 & 5 & 84 & 9 & 84 & 15 & 0.11 \\
\hline$\dot{\mathrm{VO}}_{2} / \mathrm{f}_{\mathrm{c}}, \mathrm{mL} /$ beat & 11 & 2 & 9 & 3 & 8 & 2 & 0.09 \\
\hline Systolic blood pressure, $\mathrm{mm} \mathrm{Hg}$ & 193 & 17 & 175 & 22 & 150 & 30 & 0.008 \\
\hline Diastolic blood pressure, $\mathrm{mm} \mathrm{Hg}$ & 80 & 5 & 86 & 12 & 87 & 21 & 0.82 \\
\hline Minute ventilation, $\dot{\mathrm{V}}_{\mathrm{E}}, \mathrm{L} / \mathrm{min}$ & 59.4 & 12.5 & 43.7 & 17 & 61.7 & 18.9 & 0.002 \\
\hline Breathing frequency, $\mathrm{b} / \mathrm{min}$ & 32 & 6 & 37 & 7 & 43 & 8 & 0.01 \\
\hline Tidal volume, $\mathrm{V}_{\mathrm{T}}, \mathrm{L}$ & 1.88 & 0.36 & 0.98 & 0.45 & 1.32 & 0.36 & $<0.0001$ \\
\hline $\mathrm{V}_{\mathrm{T} \text { peak }} /$ vital capacity & 0.5 & 0.06 & 0.47 & 0.1 & 0.45 & 0.09 & 0.46 \\
\hline$\dot{\mathrm{V}}_{\mathrm{E}} /$ maximum voluntary ventilation & 0.45 & 0.11 & 0.75 & 0.22 & 0.56 & 0.12 & 0.0001 \\
\hline$\dot{\mathrm{V}}_{\mathrm{E}} / \mathrm{CO}_{2}$ output & 30.1 & 5 & 37.1 & 5.9 & 37.7 & 3.9 & 0.002 \\
\hline $\mathrm{S}_{\mathrm{P}} \mathrm{O}_{2}, \%$ & 94.6 & 4 & 92.9 & 4.5 & 98.3 & 1.1 & 0.009 \\
\hline Borg dyspnea at peak & NA & NA & 6.1 & 1.5 & 4.8 & 1.3 & 0.05 \\
\hline
\end{tabular}

COPD: chronic obstructive pulmonary disease, $\mathrm{CHF}$ : congestive heart failure, $\mathrm{S}_{\mathrm{P}} \mathrm{O}_{2}$ : oxyhemoglobin saturation measured with pulse oximetry. 


\subsection{Contrast of Leg Muscles to Ventilatory Muscles}

In comparison to the leg muscles of all participants, the ventilatory muscles usually had lower $\mathrm{HHb}, \mathrm{HbO}_{2}$, and TOT and higher $\mathrm{S}_{\mathrm{m}} \mathrm{O}_{2}$ values at rest and during unloaded and loaded exercise (Figure 2). The lower value of $\mathrm{S}_{\mathrm{m}} \mathrm{O}_{2}$ in the ventilatory muscles than in the leg muscles during loaded exercise only occurred in the CHF group (please see below and Figure 3).

(A)

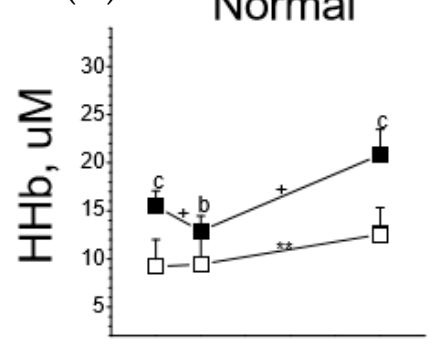

(B)

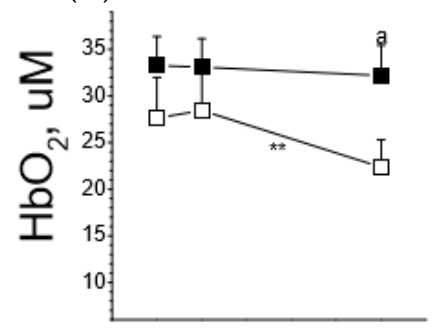

(C)

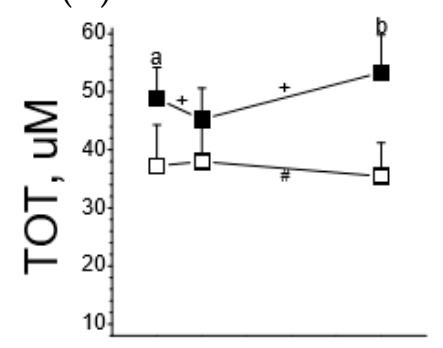

(D)

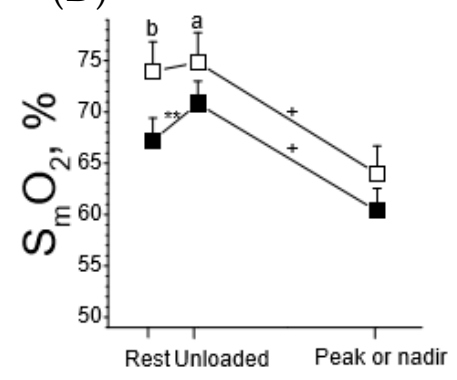

COPD
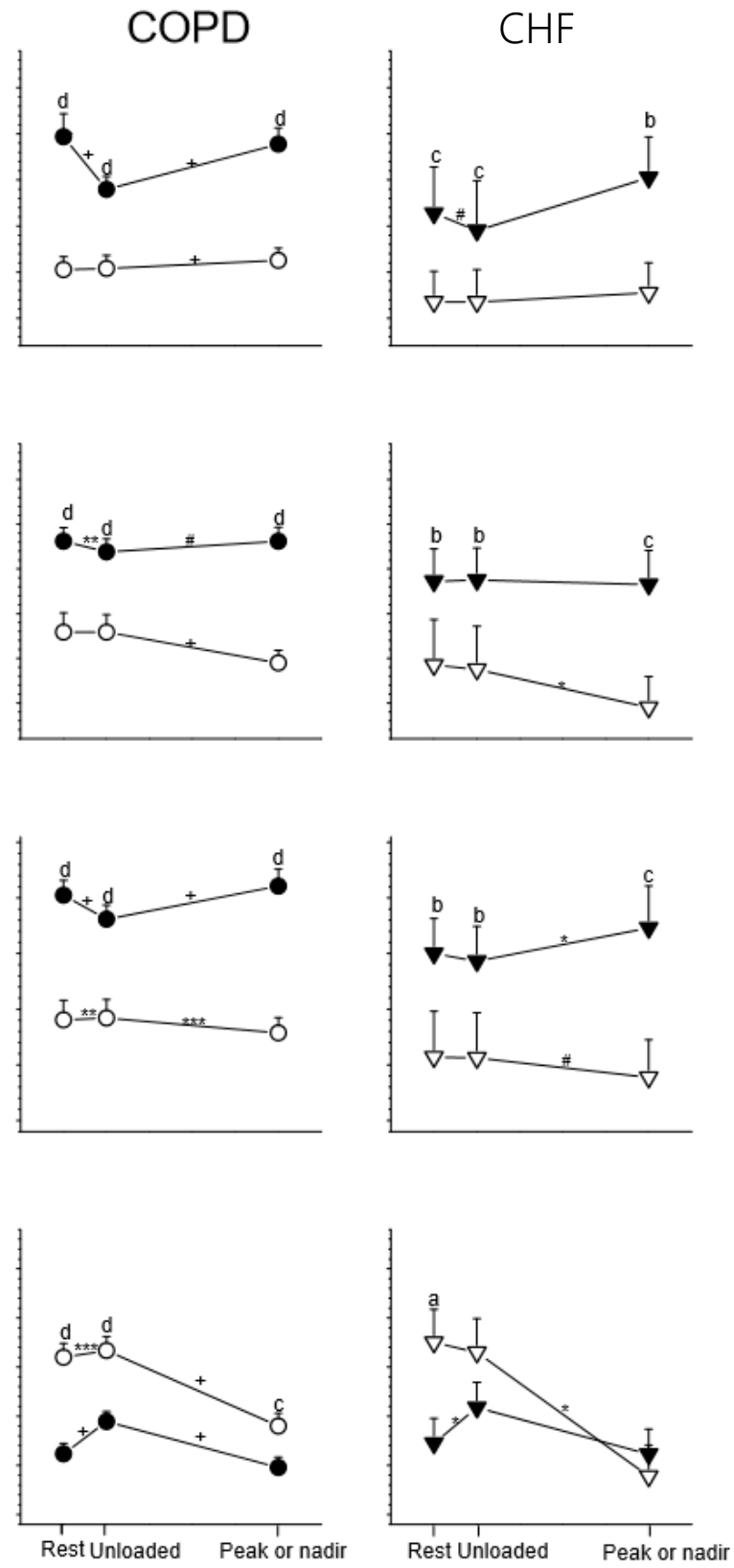

Figure 2. Tissue deoxygenation ( $\mathrm{HHb}$, row $(\mathbf{A}))$, oxygenation $\left(\mathrm{HbO}_{2}\right.$, row $\left.(\mathbf{B})\right)$, total blood capacity (TOT, row (C)), and saturation $\left(\mathrm{S}_{\mathrm{m}} \mathrm{O}_{2}\right.$, row (D)) of leg muscles (solid symbol) and ventilatory muscles (open symbol) in response to incremental exercise in healthy subjects (Normal) and subjects with chronic obstructive pulmonary disease (COPD) and congestive heart failure (CHF). Paired $t$ tests were used for comparison between two muscles at three stages of the exercise test, respectively: ${ }^{\mathrm{a}} p<0.05$, ${ }^{\mathrm{b}} p<0.01,{ }^{\mathrm{c}} p<0.001,{ }^{\mathrm{d}} p<0.0001$; paired $t$ tests were used for comparisons of changes in variables between rest and unloaded exercise and between unloaded exercise and at peak (or nadir) exercise, respectively: ${ }^{\#} p<0.1,{ }^{*} p<0.05,{ }^{* *} p<0.01,{ }^{* * *} p<0.001,{ }^{+} p<0.0001$. 


\subsection{Leg Muscles in the Three Groups}

To better visualize the dynamic changes in oxygenation of leg and ventilatory musculatures for comparisons across the three groups, the same dataset as Figure 2 was used (Figure 3). At rest, the healthy group tended to have higher $\mathrm{HbO}_{2}$ and significantly higher $\mathrm{S}_{\mathrm{m}} \mathrm{O}_{2}(p<0.0001)$, whereas the COPD group tended to have higher $\mathrm{HHb}(p<0.1)$ and the CHF group tended to have lower $\mathrm{HbO}_{2}$ $(p<0.1)$ and TOT (Figure 3, left panels). Across the three groups, scenarios in the $\mathrm{Hb}$ variables during unloaded and loaded exercise were the same as at rest. Unloaded exercise did not change $\mathrm{HbO}_{2}$ but decreased $\mathrm{HHb}$, thereby decreasing TOT and increasing $\mathrm{S}_{\mathrm{m}} \mathrm{O}_{2}$ in all subjects (Figure 3). Although unloaded exercise changed the four $\mathrm{Hb}$ variables, the directions and levels of change were similar across the three groups. Loaded exercise significantly increased $\mathrm{HHb}$ in all subjects (all $p<0.0001$ ) but did not significantly change $\mathrm{HbO}_{2}$, thereby significantly increasing TOT and decreasing $\mathrm{S}_{\mathrm{m}} \mathrm{O}_{2}$ (Figure 3). Although loaded exercise changed the four $\mathrm{Hb}$ variables, the directions and levels of change were similar across the three groups.
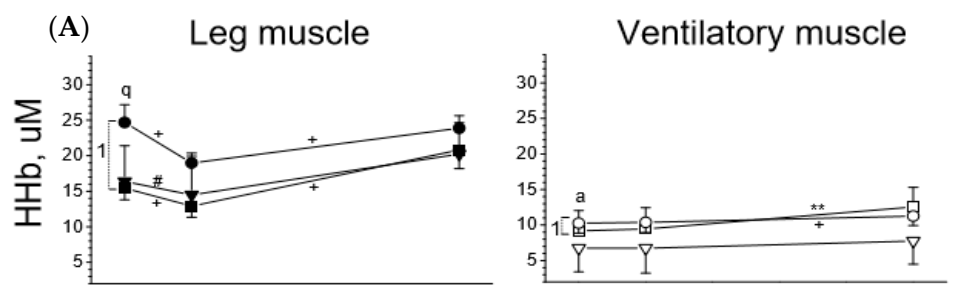

(B)
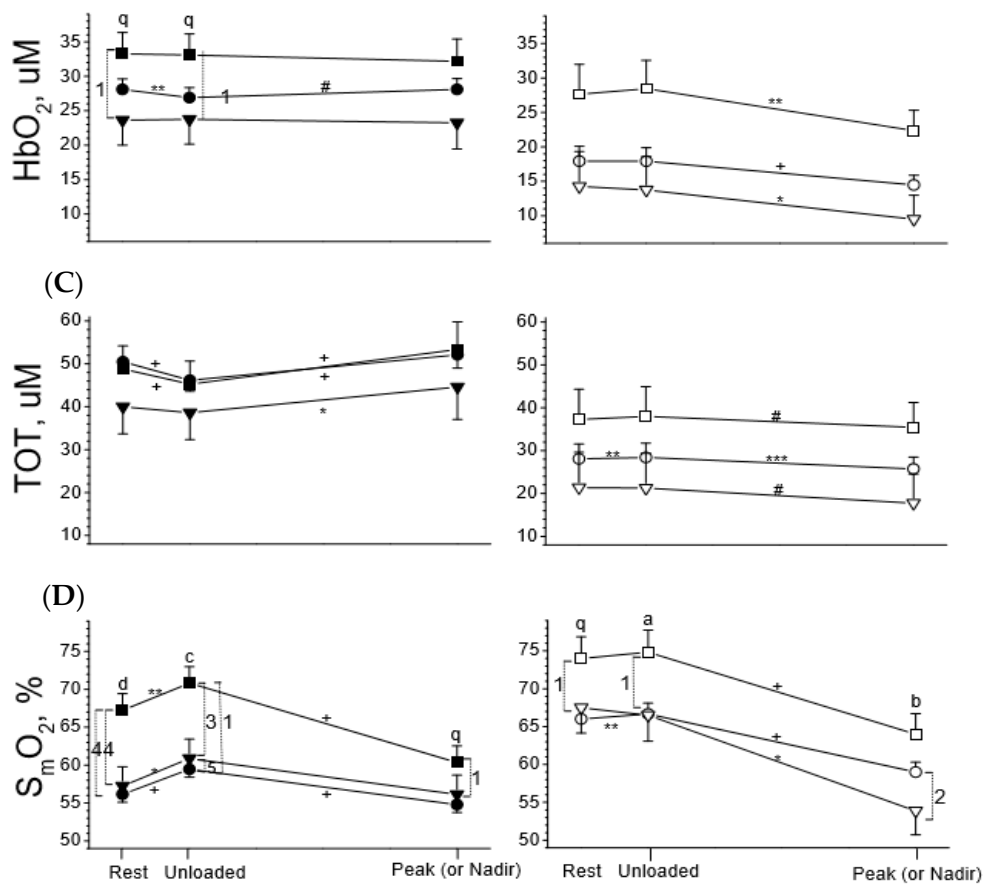

Figure 3. Tissue deoxygenation $(\mathrm{HHb}$, row $(\mathbf{A}))$, oxygenation $\left(\mathrm{HbO}_{2}\right.$, row $\left.(\mathbf{B})\right)$, total blood capacity (TOT, row $(\mathbf{C})$ ), and saturation $\left(\mathrm{S}_{\mathrm{m}} \mathrm{O}_{2}\right.$, row (D)) of leg muscles (left panels, solid symbols) and ventilatory muscles (right panels, open symbols) in response to incremental exercise in healthy subjects (square symbol) and subjects with chronic obstructive pulmonary disease (COPD, circle symbol) and congestive heart failure ( $\mathrm{CHF}$, down triangle symbol). ANOVA was used for group comparisons at 3 stages of exercise, respectively: ${ }^{\mathrm{q}} p<0.1,{ }^{\mathrm{a}} p<0.05,{ }^{\mathrm{b}} p<0.01,{ }^{\mathrm{c}} p<0.001,{ }^{\mathrm{d}} p<0.0001$; Paired $t$ tests were used for comparisons of changes in variables between rest and unloaded exercise and between unloaded exercise and at peak (or nadir) exercise, respectively: ${ }^{*} p<0.1,{ }^{*} p<0.05,{ }^{* *} p<0.01,{ }^{* * *} p<0.001$, ${ }^{+} p<0.0001$. Comparisons of variables between two groups of subjects, Arabic numbers ${ }^{5} p<0.1$, ${ }^{1} p<0.05,{ }^{2} p<0.01,{ }^{3} p<0.001,{ }^{4} p<0.0001$. 


\subsection{Ventilatory Muscles in the Three Groups}

At rest, the healthy subjects had modestly higher or tended to have higher $\mathrm{HbO}_{2}$, TOT, and $\mathrm{S}_{\mathrm{m}} \mathrm{O}_{2}$ (Figure 3 , right panels, $p<0.1$ ). Across the three groups, differences in the $\mathrm{Hb}$ variables during unloaded and loaded exercise were the same as at rest. Unloaded exercise did not change the four variables for all subjects, except that TOT and $\mathrm{S}_{\mathrm{m}} \mathrm{O}_{2}$ were slightly increased in the COPD group (Figure 3). Loaded exercise significantly increased $\mathrm{HHb}$ (except the CHF group) and decreased $\mathrm{HbO}_{2}$ (all $p<0.05-0.0001$ ), thereby slightly decreasing TOT $(p<0.1-0.001)$ and significantly decreasing $\mathrm{S}_{\mathrm{m}} \mathrm{O}_{2}(p<0.05-0.0001)$. The CHF group had significantly lower $\mathrm{S}_{\mathrm{m}} \mathrm{O}_{2}$ than the COPD group at peak exercise $(p<0.01)$.

\section{5. $\mathrm{S}_{m} \mathrm{O}_{2}$ Data at Peak Exercise versus Demographic, Lung Function and CPET Data}

Nadir $\mathrm{S}_{\mathrm{m}} \mathrm{O}_{2}$ levels obtained from the two musculatures had the best correlations with the demographic, lung function and CPET data at peak exercise compared to the other three $\mathrm{Hb}$ variables. For simplicity, only $\mathrm{S}_{\mathrm{m}} \mathrm{O}_{2}$ was reported. Nadir $\mathrm{S}_{\mathrm{m}} \mathrm{O}_{2}$ of the leg muscles was related to age $(r=-0.36$, Table 3), OCD ( $r=0.30)$, maximal inspiratory pressure (MIP) \%pred $(r=0.47)$, and some peak exercise variables, including heart rate $(r=0.30), \dot{\mathrm{V}}_{\mathrm{E}} /$ maximal voluntary ventilation (MVV) ratio $(r=-0.30)$, Borg score $(r=-0.49), \mathrm{S}_{\mathrm{P}} \mathrm{O}_{2}(r=0.37)$, and nadir $\dot{\mathrm{V}}_{\mathrm{E}} / \mathrm{V} \mathrm{CO}_{2}(r=-0.30)$. Nadir $\mathrm{S}_{\mathrm{m}} \mathrm{O}_{2}$ of the ventilatory muscles was related to age $(r=-0.30)$, OCD $(r=0.29)$, cigarette smoking $(r=-0.26)$, MIP \%pred $(r=0.56)$, and some peak exercise variables including heart rate $(r=0.29)$ and $\dot{\mathrm{V}}_{\mathrm{E}} / \mathrm{MVV}$ ratio $(r=-0.34)$.

Table 3. Correlation coefficient $(r)$ of oxygenation saturation of muscles at peak exercise with demographics, lung function and peak/nadir exercise in all subjects.

\begin{tabular}{|c|c|c|}
\hline Demographics & Vastus Lateralis $(r)$ & Serratus Anterior $(r)$ \\
\hline Age & $-0.36 * *$ & $-0.30 *$ \\
\hline OCD & $0.30 *$ & $0.29 *$ \\
\hline Cigarette & -0.13 & -0.26 * \\
\hline BMI & $0.21^{\mathbb{I I}}$ & $0.23^{\mathbb{I I}}$ \\
\hline \multicolumn{3}{|l|}{ Lung function } \\
\hline $\mathrm{MIP} \%$ & $0.47^{\dagger}$ & $0.56^{++}$ \\
\hline $\mathrm{MEP} \%$ & 0.07 & 0.14 \\
\hline $\mathrm{FVC} \%$ & -0.03 & -0.13 \\
\hline $\mathrm{FEV}_{1} \%$ & 0.12 & 0.11 \\
\hline $\mathrm{FEV}_{1} / \mathrm{FVC}$ & 0.24 II & 0.11 \\
\hline \multicolumn{3}{|l|}{ Exercise } \\
\hline HR & $0.30 *$ & $0.29 *$ \\
\hline Watt $\%$ & -0.02 & 0.02 \\
\hline $\mathrm{VO}_{2} \%$ & -0.08 & 0.03 \\
\hline $\mathrm{VO}_{2} / \mathrm{HR}$ & 0.01 & 0.13 \\
\hline $\mathrm{dVO}_{2} / \mathrm{dWR}$ & 0.07 & 0.05 \\
\hline $\mathrm{V}_{\mathrm{E}} \%$ & $-0.33 * *$ & $-0.34 * *$ \\
\hline $\mathrm{V}_{\mathrm{E}} / \mathrm{VCO}_{2}$ & $-0.30 *$ & -0.21 \\
\hline Borg & $-0.49^{+}$ & -0.15 \\
\hline $\mathrm{S}_{\mathrm{P}} \mathrm{O}_{2}$ & $0.37^{* *}$ & 0.04 \\
\hline $\mathrm{V}_{\mathrm{T}} / \mathrm{VC}$ & -0.09 & -0.13 \\
\hline $\mathrm{B}_{\mathrm{f}}$ & 0.03 & -0.08 \\
\hline
\end{tabular}

OCD: oxygen-cost diagram, Cigarette: in pack $\times$ years, BMI: body mass index, MIP: maximal inspiratory pressure, MEP: maximal expiratory pressure, FVC: forced vital capacity, $\mathrm{FEV}_{1}$ : forced expired volume in one second, $\mathrm{HR}$ : heart rate, d: slope, $\mathrm{VO}_{2}$ : oxygen uptake, $\mathrm{V}_{\mathrm{E}}$ : minute ventilation, $\mathrm{WR}$ : work rate, $\mathrm{VCO}_{2}$ : ratio of $\mathrm{V}_{\mathrm{E}}$ and carbon dioxide output, $\mathrm{S}_{\mathrm{P}} \mathrm{O}_{2}$ : oxyhemoglobin measured by pulse oximetry, $\mathrm{V}_{\mathrm{T}} / \mathrm{VC}$ : ratio of tidal volume and vital capacity, $\mathrm{B}_{\mathrm{f}}$ : breathing frequency. The numbers in bold indicate $p<0.05$. ${ }^{\mathbb{1}} 0.05<p<0.1{ }^{*} p<0.05,{ }^{* *} p<0.01,{ }^{\dagger} p<0.001$, ${ }^{++} p<0.0001$.

\section{Discussion}

The important findings of this study are that the leg muscles of all participants had higher $\mathrm{HHb}, \mathrm{HbO}_{2}$ and TOT but lower $\mathrm{S}_{\mathrm{m}} \mathrm{O}_{2}$ than the ventilatory muscles throughout the tests. In addition, 
the healthy controls had higher levels of $\mathrm{S}_{\mathrm{m}} \mathrm{O}_{2}$ and $\mathrm{HbO}_{2}$ in both muscles throughout the tests, whereas the COPD group had higher $\mathrm{HHb}$ levels and the $\mathrm{CHF}$ group had lower $\mathrm{HbO}_{2}$ levels, which is consistent with a previous report [51]. Unloaded exercise changed the four $\mathrm{Hb}$ variables of the leg muscles more prominently than those of the ventilatory muscles. Loaded exercise increased $\mathrm{HHb}$ but did not change $\mathrm{HbO}_{2}$, thereby increasing TOT and decreasing $\mathrm{S}_{\mathrm{m}} \mathrm{O}_{2}$ in the leg muscles. However, loaded exercise conversely decreased $\mathrm{HbO}_{2}$ and TOT in the ventilatory muscles and decreased $\mathrm{S}_{\mathrm{m}} \mathrm{O}_{2}$ to a lower level in the diseased subjects than in the healthy subjects (Figure $3, p<0.01$ ) and to a further lower level in the CHF group $(p<0.01)$. The correlation study revealed some factors that were detrimental and others beneficial to $\mathrm{SmO}_{2}$ and by interventions, the $\mathrm{SmO}_{2}$ might be improved (please see Section 4.5. Correlations). The findings of this study highlight the feasibility of using fdNIRS and the importance of measurements of muscle oxygenation and blood volume changes in addition to clinical assessment tools for patients with exertional dyspnea, and thus offer a critical reference for clinicians in the management of such patients with ventilatory muscle weakness as ventilatory muscle weakness may aggravate ventilation-perfusion mismatch during exercise [52].

\subsection{Re-Definition of $\mathrm{HHb}, \mathrm{HbO}_{2}, \mathrm{TOT}$, and $\mathrm{S}_{m} \mathrm{O}_{2}$}

Changes in $\mathrm{HHb}$ and $\mathrm{HbO}_{2}$ were reported to indicate oxidative metabolism [5], i.e., that $\mathrm{HHb}$ represents tissue oxygen consumption and $\mathrm{HbO}_{2}$ represents tissue oxygen perfusion or delivery, respectively. TOT was reported to indicate recruitment strategies of circulation [5], also called $\mathrm{O}_{2}$ diffusion capacity $[44,53]$ or to be related to vessel conductance [54] and $\mathrm{S}_{\mathrm{m}} \mathrm{O}_{2}$ was reported to indicate the balance between muscle oxygen supply and demand [55].

However, muscle metabolism or blood flow cannot be evaluated using NIRS without performing arterial or venous occlusion [17,56-58] because $\mathrm{HbO}_{2}$ and $\mathrm{HHb}$ levels reflect the instantaneous balance between muscular oxygen consumption and delivery and probably need to take into consideration $\mathrm{O}_{2}$ store in the tissue of interest. During unloaded leg exercise, the leg muscles are the most active muscles (at least compared to ventilatory muscles), despite the workload being " $\sim$ zero" watts, and pump $\mathrm{HHb}$ blood into veins and thus decrease $\mathrm{HHb}$ but preserve $\mathrm{HbO}_{2}$ (due to " zero" watts, i.e., very light workload), thereby decreasing TOT and increasing $\mathrm{S}_{\mathrm{m}} \mathrm{O}_{2}$. Oxygen consumption and total blood flow during this time cannot be lower than those at rest, so that $\mathrm{HHb}$ is not only an indicator of oxygen consumption but also an indicator of venous blood that is pumped away (i.e., decrease in $\mathrm{HHb}$ signal) or stored if any (i.e., increase in $\mathrm{HHb}$ signal) and therefore, TOT cannot represent blood flow but blood capacity (or volumes) of the tissue of interest [36,44,53,54]. Mancini et al. [38] and Terakado et al. [38,59] used isosbestic points of $800 \mathrm{~nm}$ and $805 \mathrm{~nm}$ to indicate blood volume rather than using TOT. Hirai et al. defined $\mathrm{O}_{2}$ diffusion as "flux of $\mathrm{O}_{2}$ driven by $\mathrm{O}_{2}$ pressure differential between the capillary and the intramyocyte milieu operating against a finite $\mathrm{O}_{2}$ diffusing capacity" [13], which is quite different from the definitions reported in prior studies [44,53]. The difference between $\mathrm{HbO}_{2}$ and $\mathrm{HHb}$ represents the balance between oxygen supply and extraction, and it probably resembles the meaning of $\mathrm{S}_{\mathrm{m}} \mathrm{O}_{2}$, although not mathematically $[16,58]$. Of note, Legrand et al. used the difference in the absorption between 730 and $850 \mathrm{~nm}$ to indicate muscle oxygenation [14], whereas Mancini et al. used the difference in absorption between 800 and $760 \mathrm{~nm}$ for hemoglobin oxygen saturation [38], Mancini et al. and Chuang et al. used the difference in absorption between 760 and $850 \mathrm{~nm}$ for muscle deoxygenation [18,37], and Terkado et al. and Watanabe et al. used $\mathrm{HbO}_{2}=\mathrm{x}_{1} \Delta \mathrm{A} 780+\mathrm{y}_{1} \Delta \mathrm{A} 805+$ $\mathrm{z}_{1} \Delta \mathrm{A} 830$ and $\mathrm{HHb}=\mathrm{x}_{2} \Delta \mathrm{A} 780-\mathrm{y}_{2} \Delta \mathrm{A} 805-\mathrm{z}_{2} \Delta \mathrm{A} 830\left(\mathrm{x}_{1,2}, \mathrm{y}_{1,2}, \mathrm{z}_{1,2}\right.$, coefficients; $\Delta \mathrm{A}$, change in the absorbance) $[54,59]$. In addition, Lucero et al. reported $\mathrm{HbO}_{2}$ and $\mathrm{HHb}$ values without providing the formula using the wavelengths [57].

\subsection{Leg Muscles Versus Ventilatory Muscles}

Blood volume has been reported to be higher in leg muscles than in ventilatory muscles [17,59]. This may have caused a higher blood volume per unit of tissue of interest in the leg muscles than in the ventilatory muscles and thus, the systemically higher values of $\mathrm{HbO}_{2}$ and $\mathrm{HHb}$ and TOT in the leg 
muscles compared to the ventilatory muscles, which is compatible with a previous study [17]. However, $\mathrm{S}_{\mathrm{m}} \mathrm{O}_{2}$ was higher in the ventilatory muscles than in the leg muscles in this study. We speculate that the high $\mathrm{S}_{\mathrm{m}} \mathrm{O}_{2}$ in the ventilatory muscles may be related to type I/II ratio, capillary/muscle density or capillary/myofibril ratio. Aerobic muscle enzyme activities have been reported to be higher in the ventilatory muscles in patients with $\mathrm{COPD}$ and $\mathrm{CHF}$, whereas some anaerobic muscle enzyme activities have been reported to be higher in the quadriceps femoris [1]. In contrast to the leg muscles, the ventilatory muscles do not change much during unloaded exercise as they are involved only when exercise progresses to $>85 \%$ of peak $\mathrm{VO}_{2}$ [44]. This might be different from the sternocleidomastoid muscle which usually demonstrates increased activity at 30\% of maximal inspiratory pressure in patients with COPD [60].

\subsection{Loaded Exercise-Leg Muscles}

In the present study, the leg muscles had preserved $\mathrm{HbO}_{2}$ and increased TOT due to the increase in $\mathrm{HHb}$ in all participants during loaded exercise, which is consistent with a report by Vogiatzis et al., who used NIRS with the IGD method to study patients with COPD [22]. This suggests that the blood flow supply was adequate or maintained to an extent that oxidative metabolism or demand or consumption (i.e., $\mathrm{HHb}$ ) increased to a larger extent. However, Reid et al. reported that $\mathrm{HbO}_{2}$ decreased in biceps in response to an incremental forearm contraction in patients with COPD [16].

In the present study, $\mathrm{HHb}$ reached a similar level under maximal exercise across the three groups despite the different physiological limitations and exercise loads. This suggests that the peak capability of skeletal muscle oxygen extraction was similar across the three groups at peak exercise with the heart rate/predicted heart rate ratio reaching a similar level (Table 2, $p=0.11$ ), and that a unique decrease in $\mathrm{S}_{\mathrm{P}} \mathrm{O}_{2}$ may contribute to the mechanism in patients with COPD (Table 2, $p=0.009$ ). This is compatible with a previous study by Lanfranconi et al., who reported that during incremental exercise, changes in $\mathrm{HHb}$ at peak exercise and $\mathrm{V}_{2}$ peak were lower in heart transplant recipients than in normal controls [49]. However, at lower exercise intensity in constant work rate exercise, they reported no difference in the kinetics of $\mathrm{HHb}$ between the two groups, despite the former having slower kinetics of $\dot{\mathrm{V}} \mathrm{O}_{2}$ and heart rate [49]. The authors reported that the peak heart rate was $133.8 \pm 3.8 \mathrm{~b} / \mathrm{min}$ in patients aged $50.4 \pm 2.6$ years versus $173.0 \pm 4.8 \mathrm{~b} / \mathrm{min}$ in normal controls aged $47.3 \pm 3.0$ years; the heart rate stress level was estimated to be $79 \%$ versus $100 \%$.

However, Katz et al. reported that in an invasive femoral venous blood study, patients with heart failure had higher oxygen extraction in leg muscles at peak exercise than healthy subjects [51]. Similarly, Zelt et al. reported that in patients with mild COPD, there was higher oxygen extraction in forearm muscles performing a continuous isometric handgrip squeeze at $20 \%$ of maximal voluntary contraction for $1.5 \mathrm{~min}$ compared to age-matched normal subjects [11]. We speculate that (1) the femoral vein and NIRS provide different information, as the former collects both superficial and deep leg veins whereas the latter collects the superficial microcirculation, and (2) all of the previous studies and the present study used different exercise protocols and different methods to calculate $\mathrm{HbO}_{2}, \mathrm{HHb}$, and TOT, and measured different groups of muscles, and that all of these factors may have caused the difference in the results.

\subsection{Loaded Exercise-Ventilatory Muscles}

In the present study, in the ventilatory muscles, loaded exercise decreased both $\mathrm{HbO}_{2}$ and TOT unequally across the three groups, which is compatible with previous studies in patients with COPD and normal subjects [14,22], suggesting that blood flow to the ventilatory muscles did not match the need for oxidative metabolism. The healthy subjects had higher $\mathrm{HbO}_{2}, \mathrm{TOT}$, and $\mathrm{S}_{\mathrm{m}} \mathrm{O}_{2}$, whereas the CHF group had lower $\mathrm{HbO}_{2}$, TOT, and $\mathrm{HHb}$, and the $\mathrm{CHF}$ group had the lowest $\mathrm{S}_{\mathrm{m}} \mathrm{O}_{2}$ at peak exercise. We speculate that the CHF group had poor perfusion in the ventilatory muscles at peak exercise, which is compatible with previous reports $[5,22,59]$. Thus, this study does not support the metaboreflex or steal phenomenon of blood redistribution during heavy exercise [14,20-22,38,59]. This phenomenon 
has also not been supported in previous reports, as both blood volumes of ventilatory muscles and leg muscles decrease from the breakpoint of muscle oxygenation (i.e., $~ 74-88 \%$ of $\dot{\mathrm{VO}}_{2 \text { peak }}$ ) to peak exercise $[14,50]$. In addition, molecular mechanisms of diaphragm muscle atrophy in patients with severe COPD have been reported to be downregulated in muscle-specific microRNA expressions and to be higher in histone deacetylase 4 and myocyte enhancer factor $2 \mathrm{C}$ protein levels [61]. Further studies are needed to investigate whether these findings are related to impaired peripheral oxygenation caused by chronic poor perfusion in ventilatory and leg muscles and whether they can be extrapolated to patients with CHF. In addition, molecular and NIRS studies on the mechanisms of muscle atrophy in both ventilatory and leg muscles are warranted.

\subsection{Correlations}

In the correlation study, aging, high ventilation demand/capacity ratio, exercise hyperventilation, and high dyspnea rating were detrimental to $\mathrm{S}_{\mathrm{m}} \mathrm{O}_{2}$, whereas inspiratory muscle strength and high heart rate and $\mathrm{S}_{\mathrm{P}} \mathrm{O}_{2}$ at peak exercise were beneficial to $\mathrm{S}_{\mathrm{m}} \mathrm{O}_{2}$. Thus, reducing ventilation demand/capacity ratio, exercise hyperventilation, and high dyspnea rating with interventions such as exercise training may improve $\mathrm{S}_{\mathrm{m}} \mathrm{O}_{2}$. On the other hand, improving inspiratory muscle strength and $\mathrm{S}_{\mathrm{p}} \mathrm{O}_{2}$ and enhancing the capacity of heart rate increase by exercise training and breathing maneuvers with $\mathrm{O}_{2}$ breathing may also improve $\mathrm{S}_{\mathrm{m}} \mathrm{O}_{2}$. Lastly, $\mathrm{VO}_{2 \text { peak }}$ \%predicted and peak work rate \%predicted were not related to any of the four $\mathrm{Hb}$ variables of both musculatures in the present study (Table 3), compatible with a previous study [54]. This indicates that oxygen extraction $(\mathrm{HHb})$ and the other three variables were not related to exercise capacity. However, changes in $\mathrm{HHb}$ at peak exercise in the leg muscles have been reported to be highly related to $\mathrm{V}_{2 \text { peak }}(r=0.9, p<0.0001)$ in patients with mitochondrial myopathy and McArdle's disease [48]. In patients with mitochondrial myopathy and McArdle's disease, myofibrils extract approximately $20 \%$ of the oxygen, whereas in normal controls, they extract approximately $70 \%$ [48]. In patients with heart failure or heart transplantation, myofibrils extract normal [49] or even higher amounts of oxygen [51].

\subsection{Study Limitations}

Age and body mass index were different across the three groups and thus, selection bias may have been introduced. The issue of choosing different exercise increments among the subjects during CPET could have affected the pattern of oxygenation/deoxygenation responses between the three groups and should be considered to be a limitation of the study. Combining the IGD technique and NIRS can improve measurements of the peripheral circulation [20-22]. Given that the present study cannot conclusively refute the steal phenomenon and that the IGD technique is sophisticated, studies using central hemodynamic response measurements with a thermodilution method combined with NIRS and IGD to investigate systemic cardiac output and local circulation of locomotor and ventilatory muscles during exercise are warranted to investigate the steal phenomenon [21,38,62]. Time intervals and levels of exercise intensity are also important when studying the steal phenomenon. Additionally, the potential mechanism(s) orchestrating the study results cannot be identified in the present study because cardiac output, systemic oxygen delivery, leg and ventilatory muscle blood flow and oxygen delivery, muscle mass morphological and structural assessments were not evaluated. Moreover, when a single probe is used on large muscles, the NIRS signals may not represent the whole musculature, as potential heterogeneity of tissue responses limits its capability [34]. The thickness of subcutaneous fat was not measured in the present study because it has been reported to be a minor factor as it is limited to $<10 \mathrm{~mm}$ [63]. For direct comparisons of $\mathrm{HHb}, \mathrm{HbO}_{2}$, and TOT between individuals when using fdNIRS, correcting for adipose tissue thickness (ATT) for these variables has been recommended [34]. In our previous report, the triceps skinfold thickness was 5.5-6.7 $\mathrm{mm}$ in patients with COPD with a body mass index ranging from $20.7 \pm 2.3$ to $22.7 \pm 3.8 \mathrm{~kg} / \mathrm{m}^{2}$ [64]. As thigh skinfold is correlated with body mass index [65], this issue is expected to be minor as most of our participants had a body mass index between $23.8 \pm 3.0$ and $26.3 \pm 3.1 \mathrm{~kg} / \mathrm{m}^{2}$. Previous studies have reported skinfolds at 
the sixth intercostal space and the anterior axillary line ranging from $6.7 \pm 2.3$ to $6.7 \pm 4.6 \mathrm{~mm}$, and a skinfold at the vastus lateralis muscle ranging from $8.6 \pm 4.6$ to $8.4 \pm 2.9 \mathrm{~mm}$ in young subjects with a BMI of 21.7 to $23.7 \mathrm{~kg} / \mathrm{m}^{2}$ [14,17], and $6.5 \pm 1.0 \mathrm{~mm}$ in middle-aged normal subjects and heart transplant recipients with a BMI of 25.1 to $26.2 \mathrm{~kg} / \mathrm{m}^{2}$ [49]. Although a reference was available to correct the NIRS signals after considering ATT, only seven male participants were included in their study, which raises concerns about its generalizability [66]. The cutaneous circulation may contribute to $\mathrm{Hb}$ NIRS signals in both muscles [67]; however, this contribution may be controversial. In normal subjects, at moderate intensity exercise and at maximal exercise, Anderson reported that total cutaneous blood flow decreased from $2 \mathrm{~L} / \mathrm{min}$ to $1 \mathrm{~L} / \mathrm{min}$ while total muscular blood flow increased from $12 \mathrm{~L} / \mathrm{min}$ to $22 \mathrm{~L} / \mathrm{min}$ [68]. To discriminate perfusive or diffusive defects as the mechanism of impaired oxygen transport [13], high-power time-resolved NIRS should be used. However, this equipment is still costly. Lastly, the sample size was small and further studies are needed with a larger number of participants. Despite these limitations, through careful interpretation and by not enrolling obese subjects, fdNIRS may still be useful to measure muscular metabolism and microcirculation.

\section{Conclusions}

This study differentiates the $\mathrm{Hb}$ oxygenation status of locomotor and ventilatory muscles between healthy and diseased subjects using frequency domain NIRS which can yield absolute values. The status of $\mathrm{Hb}$ oxygenation was different in different musculatures, and changes in oxygenation and $\mathrm{S}_{\mathrm{m}} \mathrm{O}_{2}$ in response to loaded exercise between locomotor and ventilatory muscles were related to the type of disease. When performing peak exercise, more attention should be paid to ventilatory muscles in patients with cardiopulmonary diseases, especially those with CHF.

\section{Future Perspectives}

To better understand the potential mechanisms orchestrating dynamic muscle oxygenation in different types of diseases, directly measuring cardiac output, systemic oxygen delivery, leg and ventilatory muscle blood flow and oxygen delivery, and muscle mass morphological and structural changes and molecular mechanisms of muscle atrophy concomitantly with tissue monitoring with near infrared spectroscopy is warranted. This may be also suitable for interpreting the effects of pharmacological and non-pharmacological interventions in patients with exertional dyspnea.

Author Contributions: M.-L.C.: initiated and designed the study, analyzed and interpreted the data, wrote the manuscript, and approved the version to be published. I.-F.L.: statistical analysis, revised the manuscript critically for important intellectual content, and approved the version to be published. M.-J.H.: reviewed and interpreted the data, revised the manuscript critically for important intellectual content, and approved the version to be published.

Funding: This study was supported in part by the Minister of Science and technology, Taiwan (MOST 106-2314-B-040-025).

Acknowledgments: The authors would like to thank the Ministry of Science and Technology, Taiwan, for the support in part of the study (MOST 106-2314-B-040-025).

Conflicts of Interest: The authors declare no competing financial interests.

\section{References}

1. Gosker, H.R.; Wouters, E.F.; van der Vusse, G.J.; Schols, A. Skeletal muscle dysfunction in chronic obstructive pulmonary disease and chronic heart failure: Underlying mechanisms and therapy perspectives. Am. J. Clin. Nutr. 2000, 71, 1033-1047. [CrossRef] [PubMed]

2. Aliverti, A.; Macklem, P.T. Last Word on Point: Counterpoint: The major limitation to exercise performance in COPD is 1) inadequate energy supply to the respiratory and locomotor muscles, 2) lower limb muscle dysfunction, 3) dynamic hyperinflation. J. Appl. Physiol. 2008, 105, 763. [CrossRef] [PubMed]

3. Debigare, R.; Maltais, F. The major limitation to exercise performance in COPD is lower limb muscle dysfunction. J. Appl. Physiol. 2008, 105, 751-753. [CrossRef] [PubMed] 
4. Okita, K. Skeletal muscle metabolism during exercise in chronic heart failure. In Cardiopulmonary Exercise Testing and Cardiovascular Health; Wasserman, K., Ed.; Wiley-Blackwell: Hoboken, NJ, USA, 2005; pp. $27-39$.

5. Tanaka, T.; Basoudan, N.; Melo, L.T.; Wickerson, L.; Brochard, L.J.; Goligher, E.C.; Reid, W.D. Deoxygenation of inspiratory muscles during cycling, hyperpnoea and loaded breathing in health and disease: A systematic review. Clin. Physiol. Funct. Imaging 2018, 38, 554-565. [CrossRef] [PubMed]

6. Doucet, M.; Dubé, A.J.; Oanisse, D.R.; Debigaré, R.; Michaud, A.; Paré, M.Ė; Vaillancourt, R.; Fréchette, E.; Maltais, F. Atrophy and hypertrophy signalling of the quadriceps and diaphragm in COPD. Thorax 2010, 65, 963-970. [CrossRef] [PubMed]

7. McKenzie, D.K.; Butler, J.E.; Gandevia, S.C. Respiratory muscle function and activation in chronic obstructive pulmonary disease. J. Appl. Physiol. 2009, 107, 621-629. [CrossRef]

8. Puente-Maestu, L.; Lázaro, A.; Humanes, B. Metabolic derangements in COPD muscle dysfunction. J. Appl. Physiol. 2013, 114, 1282-1290. [CrossRef]

9. Gosker, H.R.; van Mameren, H.; van Dijk, P.J.; Engelen, M.P.; van der Vusse, G.J.; Wouters, E.F.; Schols, A.M. Skeletal muscle fibre-type shifting and metabolic profile in patients with chronic obstructive pulmonary disease. Eur. Respir. J. 2002, 19, 617-625. [CrossRef]

10. Hayot, M.; Rodriguez, J.; Vernus, B.; Carnac, G.; Jean, E.; Allen, D.; Goret, L.; Obert, P.; Candau, R.; Bonnieu, A. Myostatin up-regulation is associated with the skeletal muscle response to hypoxic stimuli. Mol. Cell Endocrinol. 2011, 332, 38-47. [CrossRef]

11. Zelt, J.T.; Jones, J.H.; Hirai, D.M.; King, T.J.; Berton, D.C.; Pyke, K.E.; O’Donnell, D.E.; Neder, J.A. Systemic vascular dysfunction is associated with emphysema burden in mild COPD. Respir. Med. 2018, 136, $29-36$. [CrossRef]

12. Ribeiro, F.; Thériault, M.E.; Debigaré, R.; Maltais, F. Should all patients with COPD be exercise trained? J. Appl. Physiol. 2013, 114, 1300-1308. [CrossRef] [PubMed]

13. Hirai, D.M.; Much, T.I.; Poole, D.C. Exercise training in chronic heart failure: Improving skeletal muscle $\mathrm{O}_{2}$ transport and utilization. Am. J. Physiol. Heart Circ. Physiol. 2015, 309, H1419-H1439. [CrossRef] [PubMed]

14. Legrand, R.; Marles, A.; Prieur, F.; Lazzari, S.; Blondel, N.; Mucci, P. Related trends in locomotor and respiratory muscle oxygenation during exercise. Med. Sci. Sports Exerc. 2007, 39, 91-100. [CrossRef] [PubMed]

15. Mezzani, A.; Grassi, B.; Jones, A.M.; Giordano, A.; Corrà, U.; Porcelli, S.; Della Bella, S.; Taddeo, A.; Giannuzzi, P. Speeding of pulmonary $\mathrm{VO}_{2}$ on-kinetics by light-to-moderate-intensity aerobic exercise training in chronic heart failure: Clinical and pathophysiological correlates. Int. J. Cardiol. 2013, 167, 2189-2195. [CrossRef] [PubMed]

16. Reid, W.D.; Sheel, A.W.; Shadgan, B.; Garland, S.J.; Road, J.D. Recruitment and Deoxygenation of Selected Respiratory and Skeletal Muscles During Incremental Loading in Stable COPD Patients. J. Cardiopulm. Rehabil. Prev. 2016, 36, 279-287. [CrossRef] [PubMed]

17. Turner, L.A.; Tecklenburg-Lund, S.; Chapman, R.F.; Stager, J.M.; Duke, J.W.; Mickleborough, T.D. Inspiratory loading and limb locomotor and respiratory muscle deoxygenation during cycling exercise. Respir. Physiol. Neurobiol. 2013, 185, 506-514. [CrossRef]

18. Mancini, D.M.; La Manca, J.; Donchez, L.; Henson, D.; Levine, S. The sensation of dyspnea during exercise is not determined by the work of breathing in patients with heart failure. J. Am. Coll. Cardiol. 1996, 28, 391-395. [CrossRef]

19. Boushel, R.; Langberg, H.; Olesen, J.; Nowak, M.; Simonsen, L.; Bülow, J.; Kjaer, M. Regional blood flow during exercise in humans measured by near-infrared spectroscopy and indocyanine green. J. Appl. Physiol. 2000, 89, 1868-1878. [CrossRef]

20. Guenette, J.A.; Vogiatzis, I.; Zakynthinos, S.; Athanasopoulos, D.; Koskolou, M.; Golemati, S.; Vasilopoulou, M.; Wagner, H.E.; Roussos, C.; Wagner, P.D.; et al. Human respiratory muscle blood flow measured by near-infrared spectroscopy and indocyanine green. J. Appl. Physiol. 2008, 104, 1202-1210. [CrossRef]

21. Vogiatzis, I.; Athanasopoulos, D.; Boushel, R.; Guenette, J.A.; Koskolou, M.; Vasilopoulou, M.; Wagner, H.; Roussos, C.; Wagner, P.D.; Zakynthinos, S. Contribution of respiratory muscle blood flow to exercise-induced diaphragmatic fatigue in trained cyclists. J. Physiol. 2008, 586, 5575-5587. [CrossRef]

22. Vogiatzis, I.; Athanasopoulos, D.; Habazettl, H.; Aliverti, A.; Louvaris, Z.; Cherouveim, E.; Wagner, H.; Roussos, C.; Wagner, P.D.; Zakynthinos, S. Intercostal muscle blood flow limitation during exercise in chronic obstructive pulmonary disease. Am. J. Respir. Crit. Care Med. 2010, 182, 1105-1113. [CrossRef] [PubMed] 
23. Guenette, J.A.; Henderson, W.R.; Dominelli, P.B.; Querido, J.S.; Brasher, P.M.; Griesdale, D.E.; Boushel, R.; Sheel, A.W. Blood flow index using near-infrared spectroscopy and indocyanine green as a minimally invasive tool to assess respiratory muscle blood flow in humans. Am. J. Physiol. Regul. Integr. Comp. Physiol. 2011, 300, R984-R992. [CrossRef] [PubMed]

24. Habazettl, H.; Athanasopoulos, D.; Kuebler, W.M.; Wagner, H.; Roussos, C.; Wagner, P.D.; Ungruhe, J.; Zakynthinos, S.; Vogiatzis, I. Near-infrared spectroscopy and indocyanine green derived blood flow index for noninvasive measurement of muscle perfusion during exercise. J. Appl. Physiol. 2010, 108, 962-967. [CrossRef] [PubMed]

25. Louvaris, Z.; Habazettl, H.; Wagner, H.; Zakynthinos, S.; Wagner, P.D.; Vogiatzis, I. Near-infrared spectroscopy using indocyanine green dye for minimally invasive measurement of respiratory and leg muscle blood flow in patients with COPD. J. Appl. Physiol. 2018, 125, 947-959. [CrossRef] [PubMed]

26. Wolf, M.; Ferrari, M.; Quaresima, V. Progress of near-infrared spectroscopy and topography for brain and muscle clinical applications. J. Biomed. Opt. 2007, 12, 062104. [PubMed]

27. GOLD COPD. Global Strategy for the Diagnosis, Management, and Prevention of Chronic Obstructive Pulmonary Disease. Available online: https:/goldcopd.org/wp-content/uploads/2018/11/GOLD-2019POCKET-GUIDE-FINAL_WMS.pdf (accessed on 6 January 2019).

28. Ponikowski, P.; Voors, A.A.; Anker, S.D.; Bueno, H.; Cleland, J.G.F.; Coats, A.J.S.; Falk, V.; González-Juanatey, J.R.; Harjola, V.P.; Jankowska, E.A.; et al. 016 ESC Guidelines for the diagnosis and treatment of acute and chronic heart failure: The Task Force for the diagnosis and treatment of acute and chronic heart failure of the European Society of Cardiology (ESC) Developed with the special contribution of the Heart Failure Association (HFA) of the ESC. Eur. Heart J. 2016, 37, 2129-2200.

29. James, P.A.; Oparil, S.; Carter, B.L.; Cushman, W.C.; Dennison-Himmelfarb, C.; Handler, J.; Lackland, D.T.; LeFevre, M.L.; MacKenzie, T.D.; Ogedegbe, O.; et al. 2014 evidence-based guideline for the management of high blood pressure in adults. report from the panel members appointed to the Eighth Joint National Committee (JNC 8). JAMA 2014, 311, 507-520. [CrossRef]

30. Mahler, D.A. Clinical measurement of dyspnea. In Dyspnea, 1st ed.; Futura Publishing: Leander, TX, USA, 1990; pp. 75-126.

31. Chuang, M.L.; Lee, C.H.; Lin, I.F. Using the oxygen-cost diagram in ramp-slope selection for dyspneic patients. Intern. Med. 2010, 49, 1325-1332. [CrossRef]

32. Jobsis, F.F. Noninvasive, infrared monitoring of cerebral and myocardial oxygen sufficiency and circulatory parameters. Science 1977, 198, 1264-1267. [CrossRef]

33. Millikan, G.A. The oxymeter, an instrument for measuring continuously the oxygen saturation of arterial blood in man. Rev. Sci. Instrum. 1942, 13, 434-444. [CrossRef]

34. Barstow, T.J. Understanding near infrared spectroscopy and its application to skeletal muscle research. J. Appl. Physiol. 2019, 126, 1360-1376. [CrossRef] [PubMed]

35. Franceschini, M.A.; Wallace, D.J.; Barbieri, B.; Fantini, S.; Mantulin, W.W.; Pratesi, S.; Donzelli, G.P.; Gratton, E. Optical study of the skeletal muscle during exercise with a second generation frequency-domain tissue oximeter. SPIE Proc. 1997, 2979, 807-814.

36. Yu, G.; Durduran, T.; Lech, G.; Zhou, C.; Chance, B.; Mohler, E.R.; Yodh, A.G. Time-dependent blood flow and oxygenation in human skeletal muscles measured with noninvasive near-infrared diffuse optical spectroscopies. J. Biomed. Opt. 2005, 10, 024027. [CrossRef] [PubMed]

37. Chuang, M.L.; Ting, H.; Otsuka, T.; Sun, X.G.; Chiu, F.Y.; Hansen, J.E.; Wasserman, K. Muscle deoxygenation as related to work rate. Med. Sci. Sports Exerc. 2002, 34, 1614-1623. [CrossRef] [PubMed]

38. Mancini, D.M.; Ferraro, N.; Nazzaro, D.; Chance, B.; Wilson, J.R. Respiratory muscle deoxygenation during exercise in patients with heart failure demonstrated with near-infrared spectroscopy. J. Am. Coll. Cardiol. 1991, 18, 492-498. [CrossRef]

39. Standring, S. Gray's Anatomy: The Anatomical Basis of Clinical Practice; Elsevier: Amsterdam, The Netherland, 2015.

40. Vilozni, D.; Bar-Yishay, E.; Beardsmore, C.S.; Shochina, M.; Wolf, E.; Godfrey, S. A non-invasive method for measuring inspiratory muscle fatigue during progressive isocapnic hyperventilation in man. Eur. J. Appl. Physiol. Occup. Physiol. 1987, 56, 433-439. [CrossRef] [PubMed]

41. Wetter, T.J.; Harms, C.A.; Nelson, W.B.; Pegelow, D.F.; Dempsey, J.A. Influence of respiratory muscle work on $\mathrm{VO}(2)$ and leg blood flow during submaximal exercise. J. Appl. Physiol. 1999, 87, 643-651. [CrossRef] 
42. Agbangla, N.F.; Audiffren, M.; Albinet, C.T. Assessing muscular oxygenation during incremental exercise using near-infrared spectroscopy: Comparison of three different methods. Physiol. Res. 2017, 66, 979-985.

43. Babcock, M.A.; Pegelow, D.F.; Harms, C.A.; Dempsey, J.A. Effects of respiratory muscle unloading on exercise-induced diaphragm fatigue. J. Appl. Physiol. 2002, 93, 201-206. [CrossRef]

44. Boone, J.; Vandekerckhove, K.; Coomans, I.; Prieur, F.; Bourgois, J.G. An integrated view on the oxygenation responses to incremental exercise at the brain, the locomotor and respiratory muscles. Eur. J. Appl. Physiol. 2016, 116, 2085-2102. [CrossRef]

45. Okushima, D.; Poole, D.C.; Rossiter, H.B.; Barstow, T.J.; Kondo, N.; Ohmae, E.; Koga, S. Muscle deoxygenation in the quadriceps during ramp incremental cycling: Deep vs. superficial heterogeneity. J. Appl. Physiol. 2015, 119, 1313-1319. [CrossRef] [PubMed]

46. Chow, S.-C.; Shao, J.; Wang, H. Sample Size Calculations in Clinical Research, 2nd ed.; Chapman \& Hall/CRC: Boca Raton, FL, USA, 2008.

47. Gallagher, D.; Visser, M.; De Meersman, R.E.; Sepulveda, D.; Baumgartner, R.N.; Pierson, R.N.; Harris, T.; Heymsfield, S.B. Appendicular skeletal muscle mass: Effects of age, gender, and ethnicity. J. Appl. Physiol. 1997, 83, 229-239. [CrossRef] [PubMed]

48. Grassi, B.; Marzorati, M.; Lanfranconi, F.; Ferri, A.; Longaretti, M.; Stucchi, A.; Vago, P.; Marconi, C.; Morandi, L . Impaired oxygen extraction in metabolic myopathies: Detection and quantification by near-infrared spectroscopy. Muscle Nerve 2007, 35, 510-520. [CrossRef] [PubMed]

49. Lanfranconi, F.; Borrelli, E.; Ferri, A.; Porcelli, S.; Maccherini, M.; Chiavarelli, M.; Grassi, B. Noninvasive evaluation of skeletal muscle oxidative metabolism after heart transplant. Med. Sci. Sports Exerc. 2006, 38, 1374-1383. [CrossRef] [PubMed]

50. Boone, J.; Barstow, T.J.; Celie, B.; Prieur, F.; Bourgois, J.G. The interrelationship between muscle oxygenation, muscle activation, and pulmonary oxygen uptake to incremental ramp exercise: Influence of aerobic fitness. Appl. Physiol. Nutr. Metab. 2016, 41, 55-62. [CrossRef] [PubMed]

51. Katz, S.D.; Maskin, C.; Jondeau, G.; Cocke, T.; Berkowitz, R.; LeJemtel, T. Near-maximal fractional oxygen extraction by active skeletal muscle in patients with chronic heart failure. J. Appl. Physiol. 2015, 88, 2138-2142. [CrossRef] [PubMed]

52. Hamazaki, N.; Masuda, T.; Kamiya, K.; Matsuzawa, R.; Nozaki, K.; Maekawa, E.; Noda, C.; Yamaoka-Tojo, M.; Ako, J. Respiratory muscle weakness increases dead-space ventilation ratio aggravating ventilation-perfusion mismatch during exercise in patients with chronic heart failure. Respirology 2019, 24, 154-161. [CrossRef]

53. Davis, M.L.; Barstow, T.J. Estimated contribution of hemoglobin and myoglobin to near infrared spectroscopy. Respir. Physiol. Neurobiol. 2013, 186, 180-187. [CrossRef]

54. Watanabe, S.; Ishii, C.; Takeyasu, N.; Ajisaka, R.; Nishina, H.; Morimoto, T.; Sakamoto, K.; Eda, K.; Ishiyama, M.; Saito, T.; et al. Assessing muscle vasodilation using near-infrared spectroscopy in cardiac patients. Jpn. Circ. J. 2005, 69, 802-814. [CrossRef]

55. DeLorey, D.S.; Kowalchuk, J.M.; Paterson, D.H. Relationship between pulmonary $\mathrm{O}_{2}$ uptake kinetics and muscle deoxygenation during moderate-intensity exercise. J. Appl. Physiol. 2003, 95, 113-120. [CrossRef]

56. Hamaoka, T.; McCully, K.K.; Quaresima, V.; Yamamoto, K.; Chance, B. Near-infrared spectroscopy/imaging for monitoring muscle oxygenation and oxidative metabolism in healthy and diseased humans. J. Biomed. Opt. 2007, 12, 062105. [CrossRef] [PubMed]

57. Lucero, A.A.; Addae, G.; Lawrence, W.; Neway, B.; Credeur, D.P.; Faulkner, J.; Rowlands, D.; Stoner, L. Reliability of muscle blood flow and oxygen consumption response from exercise using near-infrared spectroscopy. Exp. Physiol. 2018, 103, 90-100. [CrossRef] [PubMed]

58. Van Beekvelt, M.C.; Colier, W.N.; Wevers, R.A.; Van Engelen, B.G. Performance of near-infrared spectroscopy in measuring local $\mathrm{O}_{2}$ consumption and blood flow in skeletal muscle. J. Appl. Physiol. 2001, 90, 511-519. [CrossRef] [PubMed]

59. Terakado, S.; Takeuchi, T.; Miura, T.; Sato, H.; Nishioka, N.; Fujieda, Y.; Kobayashi, R.; Ibukiyama, C. Early occurrence of respiratory muscle deoxygenation assessed by near-infrared spectroscopy during leg exercise in patients with chronic heart failure. Jpn. Circ. J. 1999, 63, 97-103. [CrossRef] [PubMed]

60. De Troyer, A.; Peche, R.; Yernault, J.C.; Estenne, M. Neck muscle activity in patients with severe chronic obstructive pulmonary disease. Am. J. Respir. Crit. Care Med. 1994, 150, 41-47. [CrossRef] [PubMed] 
61. Puig-Vilanova, E.; Aguiló, R.; Rodríguez-Fuster, A.; Martínez-Llorens, J.; Gea, J.; Barreiro, E. Epigenetic mechanisms in respiratory muscle dysfunction of patients with chronic obstructive pulmonary disease. PLOS ONE 2014, 9, e111514. [CrossRef] [PubMed]

62. Miller, J.D.; Hemauer, S.J.; Smith, C.A.; Stickland, M.K.; Dempsey, J.A. Expiratory threshold loading impairs cardiovascular function in health and chronic heart failure during submaximal exercise. J. Appl. Physiol. 2006, 101, 213-227. [CrossRef] [PubMed]

63. Colier, W.N.; Meeuwsen, I.B.; Degens, H.; Oeseburg, B. Determination of oxygen consumption in muscle during exercise using near infrared spectroscopy. Acta Anaesthesiol. Scand. 1995, 39, 151-155. [CrossRef]

64. Chuang, M.L.; Lin, I.F. Clinical characteristics and lung function in chronic obstructive pulmonary disease complicated with impaired peripheral oxygenation. Intern. Emerg. Med. 2014, 9, 633-640. [CrossRef]

65. Ducimetiere, P.; Richard, J.L. The relationship between subsets of anthropometric upper versus lower body measurements and coronary heart disease risk in middle-aged men. The Paris Prospective Study. I. Int. J. Obes. 1989, 13, 111-121.

66. Craig, J.C.; Broxterman, R.M.; Wilcox, S.L.; Chen, C.; Barstow, T.J. Effect of adipose tissue thickness, muscle site, and sex on near-infrared spectroscopy derived total-[hemoglobin + myoglobin]. J. Appl. Physiol. 2017, 123, 1571-1578. [CrossRef] [PubMed]

67. Grassi, B.; Pogliaghi, S.; Rampichini, S.; Quaresima, V.; Ferrari, M.; Marconi, C.; Cerretelli, P. Muscle oxygenation and pulmonary gas exchange kinetics during cycling exercise on-transitions in humans. J. Appl. Physiol. 2003, 95, 149-158. [CrossRef] [PubMed]

68. Anderson, K.L. The Cardiovascular System in Exercise; Academic Press: New York, NY, USA, 1968.

(C) 2019 by the authors. Licensee MDPI, Basel, Switzerland. This article is an open access article distributed under the terms and conditions of the Creative Commons Attribution (CC BY) license (http://creativecommons.org/licenses/by/4.0/). 